\title{
$\beta$-Tubulin genes and the basis for benzimidazole sensitivity of the opportunistic fungus Cryptococcus neoformans
}

\author{
Maria Cristina Cruz and Thomas Edlind
}

Department of

Microbiology and

Immunology, MCP

Hahnemann School of

Medicine, Allegheny

University of the Health

Sciences, 2900 Queen

Lane, Philadelphia, PA

19129, USA

\author{
Author for correspondence: Thomas Edlind. Tel: +1 215991 8377. Fax: +1 2158482271. \\ e-mail: edlind@allegheny.edu
}

\begin{abstract}
The basidiomycete Cryptococcus neoformans causes life-threatening infections in immunocompromised patients, and available chemotherapeutic agents are potentially toxic or have limited efficacy. In vitro, $C$. neoformans is very sensitive to selected benzimidazole compounds (e.g. albendazole), which act by disrupting microtubules through binding to the $\beta$-tubulin subunit. To understand the basis for this benzimidazole sensitivity, we have characterized $C$. neoformans $\beta$-tubulin genes and their expression. Analysis of PCR amplification products, genomic and CDNA clones and Southern blots identified two $\beta$-tubulin genes. TUB 1 contains seven introns, including one that splits the start codon, and encodes a 447 amino acid protein with $>80 \%$ identity to most other $\beta$-tubulins. A partial sequence of TUB2 revealed a higher density of introns and a considerably more divergent $\beta$-tubulin. The relative expression of TUB1 to TUB2 determined by reverse-transcription PCR was about $3: 1$, consistent with a more limited role for the TUB2 product. Comparisons of $\beta$-tubulin sequences from $C$. neoformans and from various benzimidazolesensitive and -resistant organisms strongly suggest that the TUB1 product represents the primary benzimidazole target. This was supported by the identification of a His6 to GIn change in TUB1 from three independently isolated albendazole-resistant mutants.
\end{abstract}

Keywords: Cryptococcus neoformans, tubulin, benzimidazole, microtubule, drug resistance

\section{INTRODUCTION}

Cryptococcus neoformans is a yeast-like fungus distinguished by the presence of a capsule. Unlike the better-known ascomycetous yeasts (e.g. Candida and Saccharomyces species), C. neoformans is a basidiomycete. This group includes a wide range of fungi, including mushrooms and many plant pathogens. $C$. neoformans itself is the most common cause of systemic mycosis in patients with AIDS (Panther \& Sande, 1990; Hay, 1991). Meningitis and, less frequently, pneumonia are the typical manifestations of cryptococcosis. C. neoformans infections can be effectively treated with amphotericin B; however, toxic reactions to this drug are common. Other agents, such as fluconazole, are

Abbreviation : RT-PCR, reverse-transcription polymerase chain reaction. The GenBank accession numbers for the sequences reported in this paper are GSDB:S: 1050831 and 1050832 . safer but less active (for reviews see Sugar et al., 1990; Powderly, 1992). Thus, there is a need for new anticryptococcal agents with lower toxicity and higher efficacy.

Recently, we reported that $C$. neoformans is very sensitive in vitro to several derivatives of a group of drugs called the benzimidazoles, which are widely used to treat helminth infections in humans and animals and as systemic fungicides in agriculture (Cruz et al., 1994). Benzimidazoles have been shown to disrupt mitosis in sensitive organisms through binding to the $\beta$-tubulin subunit of microtubules (for a review see Lacey, 1988). This interaction has been partially characterized at the molecular level through mutational analysis in model fungi (Thomas et al., 1985; Ohrbach et al., 1986; Jung \& Oakley, 1990; Fujimara et al., 1992; Jung et al., 1992; Li et al., 1996). However, the benzimidazole binding site, and the basis for the selective toxicity of these compounds, remain incompletely defined. 


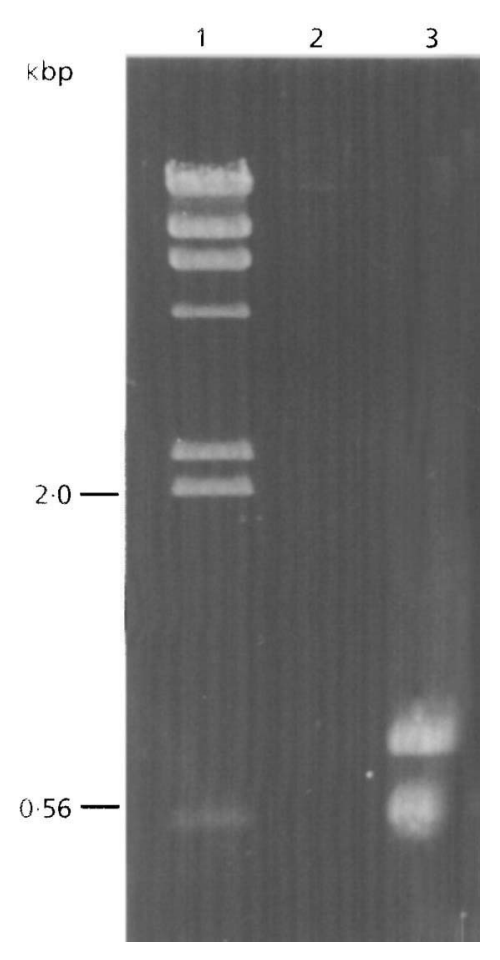

Fig. 1. PCR amplification of $\beta$-tubulin gene fragements from $C$. neoformans genomic DNA (lane 3). Lane 1, Hindlll-cleaved lambda DNA size markers (with 0.56 and $2.0 \mathrm{kbp}$ bands indicated). Lane 2 , negative control that received $\mathrm{H}_{2} \mathrm{O}$ in place of DNA.

Here we present the complete sequence of a C. neoformans $\beta$-tubulin gene (TUB1), a partial sequence of a second more divergent gene copy (TUB2), a comparison of their expression at the RNA level and the characterization of three benzimidazole-resistant isolates with mutations in TUB1. These data contribute to our understanding of benzimidazole- $\beta$-tubulin interaction, and furthermore to our general knowledge of $C$. neoformans molecular biology.

\section{METHODS}

Strains. C. neoformans strains used in this study were grown in YPD ( $1 \%$ yeast extract, $1 \%$ peptone, $2 \%$ dextrose) at $30{ }^{\circ} \mathrm{C}$ with aeration. C. neoformans $1 \mathrm{KR}$ is a clinical isolate from the blood of an AIDS patient and was kindly provided by M. Barlett (Indiana University, Indianapolis, IN, USA). C. neoformans 14116 was obtained from the American Type Culture Collection.

Isolation of DNA. Genomic DNA was prepared from C. neoformans by the procedure of Moore \& Edman (1993). Briefly, cells were harvested by centrifugation after overnight growth in YPD and resuspended in a solution of $1 \mathrm{M}$ sorbitol $/ 1 \% \quad \beta$-mercaptoethanol $/ 1 \mathrm{mg}$ mureinase $\mathrm{ml}^{-1}$ (US Biochemical). Cell lysis and protein precipitation were followed by precipitation of DNA with an equal volume of 2 propanol. DNA was resuspended in $\mathrm{H}_{2} \mathrm{O}$, treated with RNase, and precipitated again with ethanol and $7.5 \mathrm{M}$ ammonium acetate.
Isolation of RNA. An overnight culture of C. neoformans 14116 was centrifuged, resuspended in fresh YPD medium and incubated at $30^{\circ} \mathrm{C}$ for $3 \mathrm{~h}$. Cells were harvested by centrifugation and total RNA was isolated by a modification of the procedure described by Tolkacheva et al. (1994). First, cells were resuspended in cold RNA buffer $(0.5 \mathrm{M} \mathrm{NaCl}, 200 \mathrm{mM}$ Tris/ $\mathrm{HCl}, \mathrm{pH} 7 \cdot 5,10 \mathrm{mM}$ EDTA, $1 \mathrm{mg}$ mureinase $\mathrm{ml}^{-1}$ ), and broken by continuous vortexing with glass beads. The resulting lysate was extracted twice with phenol/chloroform/ isoamyl alcohol and ethanol precipitated. Total RNA was twice precipitated with $4 \mathrm{M} \mathrm{LiCl}$ followed again by ethanol precipitation.

Southern blot analysis. Genomic DNA from strain 14116 was digested with EcoRI, PstI and HindIII, electrophoresed through agarose and blotted to nitrocellulose (Davis et al., 1986). The blot was hybridized under moderately stringent conditions to a gel-purified TUB1 gene fragment labelled with ${ }^{32} \mathrm{P}$ by random priming. The TUB1 fragment was obtained by PCR amplification of C. neoformans 14116 genomic DNA with BT107-BT261R primers (see below). After exposure, TUB1 probe was eluted by addition of boiling $\mathrm{H}_{2} \mathrm{O}$, and the blot was hybridized to a TUB2 probe using the same conditions.

Cloning of C. neoformans TUB1 and TUB2 genes. Amplification by PCR of genomic DNA was the initial approach used to characterize $C$. neoformans $\beta$-tubulin genes. Oligonucleotide primers (Katiyar \& Edlind, 1994) were employed which correspond to highly conserved $\beta$-tubulin sequences adjacent to amino acid residues 107 and 261. PCR was performed as previously described (Katiyar \& Edlind, 1994) with C. neoformans 14116 genomic DNA. Two products of approximately $0.6 \mathrm{kbp}$ and $0.75 \mathrm{kbp}$ were obtained and purified from a $1 \%$ agarose gel following electrophoresis (Fig. 1). These products were cloned into M13mp19 and sequenced. Both sequences were $\beta$-tubulin-gene-related, contained introns, and were clearly distinct from each other and from other tubulin genes in the GenBank database. The genes encoding the 0.6 and $0.75 \mathrm{kbp}$ fragments were designated TUB1 and TUB2, respectively. The complete sequence of TUB1 was determined from a combination of genomic and cDNA clones isolated from lambda libraries by hybridization to a TUB1 probe (Davis et al., 1986). The genomic DNA library was kindly provided by E. Spitzer (State University of New York, Stony Brook, NY, USA) and the cDNA library by J. Edman (University of California, San Francisco, CA, USA). The sequence was subsequently confirmed from PCRamplified DNA.

PCR analysis of TUB1 and TUB2 expression. The relative expression of $C$. neoformans $\beta$-tubulin genes was determined by PCR analysis of reverse-transcribed mRNA (RT-PCR). TUB1 and TUB2 cDNAs were prepared using Mo-MuLV reverse transcriptase (New England Biolabs), $3 \mu \mathrm{g}$ total RNA, and a primer complementary to nt 1191-1210 of TUB1, which are conserved in TUB2 (Fig. 3). PCR was then performed using this primer in conjunction with primers specific for TUB1 (nt 946-966) or TUB2 (nt 51-69, not shown). Control experiments with cloned DNA demonstrated that the two primer pairs were equally specific and sensitive. Three sets of reactions were conducted for 20,22 and 25 cycles to ensure that amplification during the exponential phase was obtained. Genomic DNA was amplified in parallel for comparison to the cDNA. PCR products were compared by agarose gel electrophoresis and ethidium bromide staining.

Isolation and characterization of benzimidazole-resistant mutants. Mutants were selected by plating $1 \times 10^{7}$ cells from a 
fresh overnight culture of strain $1 K R$ on YPD plates containing $2 \mu \mathrm{g}$ albendazole $\mathrm{ml}^{-1}$. Plates were incubated at $30^{\circ} \mathrm{C}$ for $72 \mathrm{~h}$. Colony formation occurred at a frequency of $1 \times 10^{-6}$. Stability of the resistant mutants was tested by subculturing three times without the drug, followed by retesting for albendazole resistance. Genomic DNA was isolated from these mutants and their TUB1 genes were amplified by PCR, cloned, and sequenced as described above.

\section{RESULTS AND DISCUSSION}

\section{Amplification and copy number of $C$. neoformans $\beta$-tubulin genes}

PCR of genomic DNA with primers representing highly conserved $\beta$-tubulin sequences (residues 100-107 and 260-266) generated two distinct fragments of approximately 0.6 and $0.75 \mathrm{kbp}$ (Fig. 1). Cloning and sequencing revealed that both encoded $\beta$-tubulin-like proteins, and hence their corresponding genes were designated TUB1 $(0.6 \mathrm{kbp})$ and TUB2 $(0.75 \mathrm{kbp})$. To determine gene copy number, the two PCR fragments were used individually to probe a Southern blot of genomic DNA digested with three different restriction enzymes. A single major band was observed in all lanes (Fig. 2), suggesting the presence of only these two genes. In some lanes a second weak band was seen due to cross-hybridization of the TUB1 probe to the TUB2 gene, or vice versa.

\section{Analysis of TUB1 and TUB2 gene sequences}

The TUB1 partial sequence demonstrated a high degree of similarity to $\beta$-tubulin genes from other fungi and animals, while the TUB2 sequence was relatively divergent (see below). Consequently, TUB1 was of more immediate interest, and its gene, including flanking regions, was cloned from lambda libraries and sequenced in its entirety (Fig. 3). Analysis of the TUB1 sequence predicts a 447 amino acid protein. The coding sequence is interrupted by seven introns, at codons 1,21 , $90,174,308,354$ and 408. In comparison, the partial sequence of TUB2 encoding amino acids 108 to 259 (not shown) revealed five introns, at codons 138, 203, 238, 242 and 258 ; i.e. four more than found in the comparable region of TUB1. All introns are only 50-57 nt long, except the first intron of TUB1, which is $196 \mathrm{nt}$. Furthermore, all introns include 5' GTNNGY and 3' YAG splice junction signals.

Analysis of the $5^{\prime}$ flanking region of TUB1 for potential transcriptional control elements revealed a canonical TATA box (TATAAA) 250 bp upstream of the coding sequence (i.e. -250 ; Fig. 3). Other C. neoformans genes have been reported to have TATA boxes at variable positions upstream of the start codon: URA5 at -342 , MAT $\alpha$ at -106 , and LAC1 at -539 (Edman \& KwonChung, 1990; Moore \& Edman, 1993; Williamson, 1994). The wide range of TATA box locations suggests that these may not be true promoter elements. Comparison of the TUB1 $5^{\prime}$ flanking region to the corresponding regions of other $C$. neoformans genes

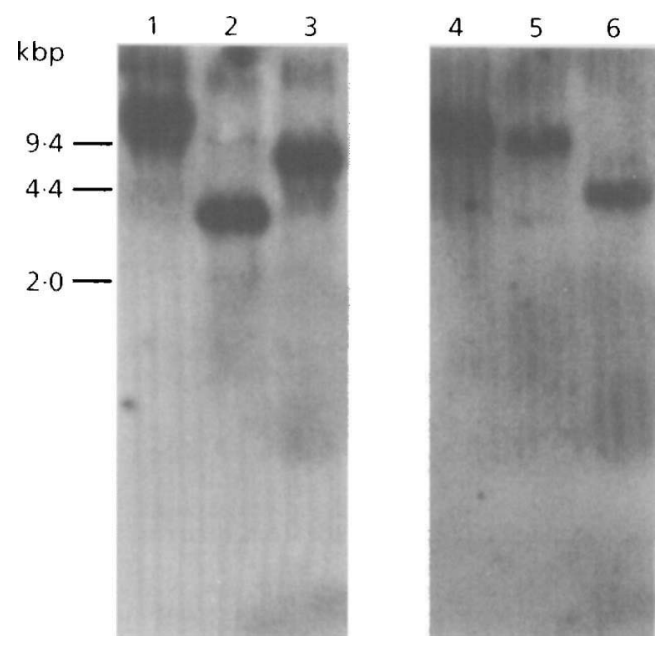

Fig. 2. Examination of $\beta$-tubulin gene copy number in $C$. neoformans by Southern blotting. Genomic DNA was cleaved with Pstl (lanes 1 and 4), EcoRI (lanes 2 and 5), or HindIII (lanes 3 and 6 ). The blot was hybridized under moderately stringent conditions to purified fragments of TUB1 (lanes 1-3) or TUB2 (lanes 4-6) and intentionally overexposed to reveal crosshybridizing bands. DNA size markers are shown.

revealed a 13 bp sequence at -87 (Fig. 3) which is also present upstream of the dihydrofolate reductase gene (at -162) (Sirawaraporn et al., 1993). Additionally, a 10 bp pyrimidine-rich sequence is directly repeated at -98 and -76 . With regard to translational initiation, analysis of the sequences adjacent to the start codon of TUB1 and 15 other C. neoformans genes revealed that 9 of 14 genes including TUB1 have A at position -3, as in many eukaryotes (Kozak, 1986); the remaining genes have either $C(3)$ or $G(2)$. No polyadenylation signal was readily identifiable in the $3^{\prime}$ flanking region of TUB1, consistent with earlier findings (Edman \& KwonChung, 1990).

\section{Analysis of TUB1 and TUB2 protein sequences}

The predicted amino acid sequences of TUB1 and TUB2 are aligned in Fig. 4 with representative $\beta$-tubulin sequences from other organisms. This alignment indicates that TUB1 encodes a conserved $\beta$-tubulin, with 81,82 , and $84 \%$ identity to $\beta$-tubulins from the ascomycete Aspergillus nidulans, human, and the basidiomycete Schizophyllum commune, respectively. On the other hand, TUB2 appears to encode a highly divergent $\beta$-tubulin with $71-73 \%$ identities to the tubulins above. The presence of a highly divergent $\beta$ tubulin along with a conserved $\beta$-tubulin has been reported in other fungi (May et al., 1987). In the region of overlap (residues 108-259), there is $73 \%$ identity between TUB1 and TUB2.

Both genes demonstrate similar codon usage. There is a strong bias for the use of $\mathrm{C}$ in the third position of Phe and Asn codons; specifically, only the AAC codon was used for Asn in both genes, 17 times in TUB1 and 9 times in the partial TUB2 sequence. 
ATCTGTTAC 9
9 GGGACTATTATGACGCTGGAACTCGTATCACTAAAGGGAAGAAATATAAATGTTGA AACGCGAGAGCCTCGCCACGTTAGGGTCAGTTATAATGCCGCGGAGTTAACGACGCGTGA 129 GGGTACGCGAACGGCGGCTGGATGCAAACACAGGAGGGGGAGGCCCTAGGGGTGTTGTTT 189 TTGGCTTGCTCTCCTCTTTTCTTTTTCTTCTTTCT TT AGTCCCA 249

Met

AGTGAGTAATGCCTGTTCACCATGGCGTGTGCATTGCACGAAGGGTCTGTGCTGATCACA 369 GTTGTGTGCCACCGCCCTCTAAAACGCGCTATGTCCACCCTGCACCTGCAACGACCCTTT $\mathbf{4 2 9}$ CTCATGCCCITATTCGCCTTTCATTATCTCTCTTATTTATATCTCTTCCCTACACTGTTG $\mathbf{4 8 9}$

ArgGluIleValHisteuGlnThrGlyGlnCygGlyAsngln 15 CACGATGGGCCGTTCAGTEOGAGAGATCGTTCACCTTCAAACOGGTCAGTGIGGTAACCA 549

IleglyalaLyopheTrp

(1)

GluValvalserGluGluHigGlYIleGlnAlaAspGlySerTyrLYsGly 38 ACCCACAGGEAGGTCGTCTCCEAGAAACACGGCATCCAGGCCGATECCTCTTACAAGGGT 669

ThrThrAspThrG InLeuGl UArgI leAsnVal TyrTYrAsngluAlaAlaAlaglyLys 58 ACCACCGACACCCAGCTCGAGCGCATCAADGTCTACTACAACEAGGCCGCGGCGGGCAAG 729

TyrVal ProArgAl aValLeuValAspLeuGluProGlyThrMetAspSerIleArgGly 78 TATETTCTTOEAGCOGTCCTCGTTEACCTOGAGCCCGEACTATECACTCCATCCGGGC 789

GlyProLeuGlySerLeuPheArgProAspAsnPhe

Valpheglyalnserclyal aglyasna TGAACAGTAGCTCATCACTATATAGTGITTTCGGCAGTCGGGTGCCGGTAACAACTEG 909

AlaLysGlyHisTyrThrGluGlyAlagluLeuvalAspservalLeuAspvalvalArg 121 CTAAGGGACACTATACAGAAGGTECCGAGCTTGTTEACTCTETTCTTGATGTTETCCGAC 969

ArgGluAlagluArgCysAspCysLeuGlnGlyPheGlnIleThrHisserLeuGlyGly 141 GAGAGGCCEAACGGTGTACTGCCTICAAGGCTTCCAGATCACCCACTCTCTCEGTGGT 1029

GIYThrGlyAl aGlyMetGlyThrLeuLeuIleserLyBI leArgGluGluPheProAsp 161 GTACCGGTGCCEGTATEGGTACACTITTEATCTCCAAGATCCGAGAAGAGTTTCCCCACC 1089

ArgmetmetcysThrPheserval Valproserprolys GAATEATGTGCACCTTCTCTGTOGTTCCTCTCCCAAGGTGCGTGCGTTTCAAACAAAAT 1149

ValserAspThrValValgluProTyrAsn 184 GCTCGAATATATGTTTAACTCTGTTCTAGGTCTCTEACACOGITGTTGAGCCTTACAACG 1209

AlaThrLeuSerValHisGlnLeuValgluAnSerAspGluThrPheCysIleAspAen 204 CCACTCTTTCOETCCATCAGCTOGTTGACAACTCTEACEACACCTTCTGTATCGACAACG 1269

GluAlaLeuTyrAspI leCysLeuArgThrLeuLysLeuSerThrProThrTyrGlyAsp 224 AGECCCTCTATEACATTTGCTTECGTACTCTCAAGCTCTCCACCCCCACATATGGTGACT 1329

LeuAsnHisLeuValserValValMetserGlyValThrThrcysLeuArgPheProGly 244 TEAACCATCTCETCTCTETCETTATETCTEGTETCYCCACATETCTTCETTTCCCOGETC 1389

GlnLeuAsnSerAspLeuArgLysLeuAl aValAsnMetVal ProPheProArgLeuHis 264 AGCTTAACTCTEACCTTCEAAGTTEGCCGTTAACATGGTECCCTTCCCTOGTCTTCATT 1449

PhePheMetValGiyPheAlaProLeuThrAlaArgGlyserAlaSerTyrargAlaval 284 TCTTCATEGTCEECTTCGCGCCTCTCACOGCCCGAGGCTCOECTAGCTACOGTECCGTCA 1509

ThrVal Progl uLeuThrGlnglnMet PheAspAlaLysAsnMetMetAlaAlaserAsp 304 COGTTCCTENGCTTACTCAGCAAATGTTIGACGCCAAGAACATEATEGCTGCCTCTEACC 1569

ProArghisGly

308

308

ArgTyrLeuThrValAlaCysTYrTyrArgGlyLysValserMetLyoGluValGlu 327 TAGCEATACCTCACOGTCGCATECTATTATCGAGGCAAGGTTTCGATEAAGGAGGTTEA 1689

AspGinI leGlnSerValGlnAl aLysAsnSerAl aTyrPheValGluTrpI leProGly 347 GACCAGATTCAGTCTGTCCAGGCCAAGAACTCCECTTACTTTGTTGAGTGGATTCCCECA 1749

AsnIleserAlaAlaglncys

AACATCTCCECOGOGCAATGGTGAGTTCAAATAATTATCATCTAGGAACTTCGCTTACGG 1809

AspIleProProArgGlyLeuLysMetSerSerThrPheIle 368 GAGCAATAATTGTTTAGTGACATCCCTCCTCGCGGTCTCAAGATGTCCTCTACCTTCATC 1869

CysAsnSerThrSerIleGlnSerLeuPheLysArgIleGlyGluGlnPheSerAlaMet 388 TGCAACTCGACTTCCATCCAGTCGCFTTTCAAGCGTATCGGCGAGCAGTTCTCTGCCATG 1929
TyrArgArgLysAlaPheValHisTrpTyrThrGlyGluGlyMetAspgluLeuGluPhe 408 TACAGGCGAAAGGCTITCGRACATTEGTACACAGGAGAGGGATEGATGAGCTTGANTT 1989

SerGluAla 411 GTAAGCATCTTGCCATTTTTTTCCCGTAACAGATAAGTAACAATAGTGGTTAGTCTEAAGC 204

GluSerAsnLeuGlnAspLeuValserGluTyrMetGlnTyrGlnGluAlaGlyAlaAsp 431 CGAATCCAACTTGCAAGACCTEGITTCCGAGIACATECAGTACCAGGAGCOERAGCEE 2109

Aspglur letyrglyAspglugluI leProIl egluglugluglumetend $\quad 447$ OEACGAAATCTATEGTGATEAGGAGATCCCCATTGAGGMGCMGEMGATETAAGGTCTCCT 2169 CATCCCTATGTTGCCCCTTCTACCCCACATTTACCCTTTGCATCCTGTCGCACCCCACCA 2229 CCACAGCGACTATAAGGTCGTTGGGTTTTGCTAAAGGTTTATCTTATTCCCCGCATCTAT 2289 ATATCCCCCCCTTTCCTTTTTGCCTCACCCGGAGGTTGAGTTCTCCGATGTCTCGCTGAT 2349 GAGACGGTGTGCTGCATACTTCGACATTCITTTCAGTGATTGGTCTCTACAGTTCTATGC 2409 AACTTGTGAGGCCTGG (poly A)

2425

Fig. 3. Nucleotide and predicted amino acid sequences of $C$. neoformans TUB1. The coding region (bold) is interrupted by seven introns. In the $5^{\prime}$ flanking region a TATA box and two $10 \mathrm{bp}$ direct repeats are underlined; a 13 bp sequence also present in the promoter region of the $C$. neoformans DHFR gene is double-underlined.

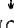

TUB1 MREIVHLOTGOCGNOIGAKFWEVVSEEHGIQADGSYKGTTDTOLERINVYYNEAAAGKYV 60

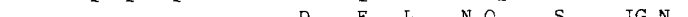

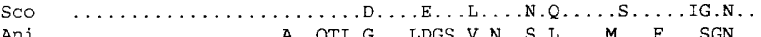

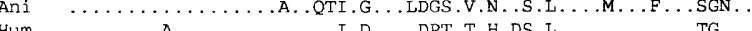

TUB1 PRAVLVDLEPGTMDSIRGGPLGSLFRPDNFVFGOSGAGNNWAKGHYTEGAELVDSVLDVV 12

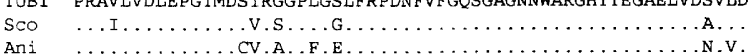

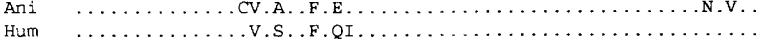

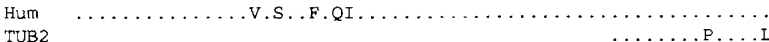

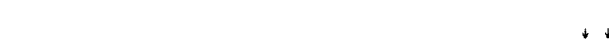

TUBI RREAERCDCLQGFQITHSLGGGTGAGMGTLLISKIREEFPDRMMCTFSVVPSPKVSDTVV 180

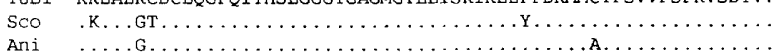

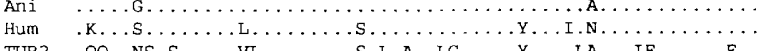

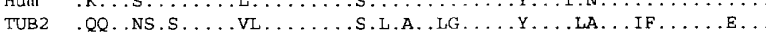

TUB1 EPYNATLSVHQLVENSDETFCIDNEALYDICLRTLKLSTPTYGDLNHLVSVVMSGVTTCL 240

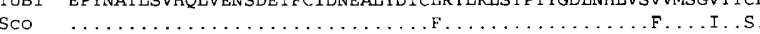

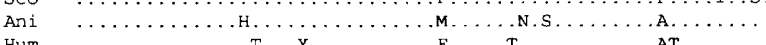

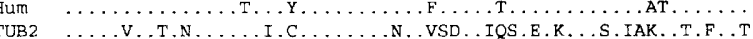

RFPGQLNSDLRKLAVNMVPFPRLHFFMVGFAPLTARGSASYRAVTVPELTQQMFDAKNMM 300

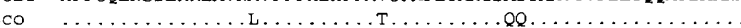

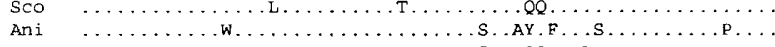

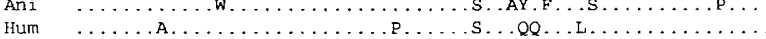

TUB2

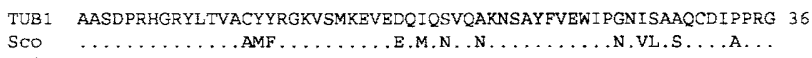

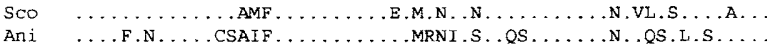

Ani
Hum

TUB1 LKMSSTFICNSTS IQSLFKRIGEQFSAMYRRKAFVHWYTGEGMDELEFSEAESNLQDLVS 420

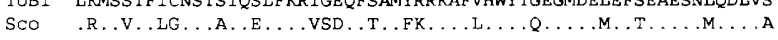

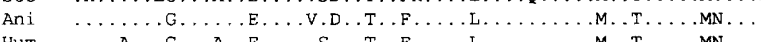

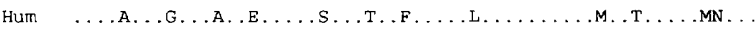

TUB1 EYMQYQEAGADDEIYGDEEIPIEEEEM 447

$\begin{array}{ll}\text { Sco } & \text { Q...D.TVEE.GEYB. .VIEDQ. } \\ \text { Ani } & \text {-Q...D.SISEGEEEYA.EE.M.G. }\end{array}$

Hum WQ..D.T.EE.GEFE. .AEE.VA

Fig. 4. Alignment of $\beta$-tubulin amino acid sequences from $C$ neoformans (TUB1, TUB2), S. commune (Sco; Russo et al., 1992), A. nidulans benA (Ani; May et al;, 1987) and human (Hum; Lewis et al. 1985). Residues identical to the TUB1 sequence are represented by dots. Arrows indicate residues implicated in benzimidazole activity $(6,165,167,198,200$ and 241). The His6 to Gln (Q) mutation identified in $3 \mathrm{C}$. neoformans albendazoleresistant mutants is noted. 


\section{Relative expression of TUB1 and TUB2}

Using RT-PCR with gene-specific primers, the relative levels of TUB1 and TUB2 mRNA were compared. As shown in Fig. 5, after 22 cycles (lanes 8-11) the amplification was still in linear phase; i.e. had not plateaued as in lanes $12-15$. From a comparison of lanes 9 and 11 , there appears to be approximately threefold less TUB2 compared to TUB1 transcript, while in lanes 13 and 15 both transcripts are readily detectable and the difference is approximately twofold. While TUB2 is clearly transcribed, its lower level, along with its more divergent sequence, suggests a more limited and specialized role for its $\beta$-tubulin. Further evidence for this is provided by the analysis below.

\section{Correlation with benzimidazole sensitivity}

Mutational studies using model fungi have implicated $\operatorname{six} \beta$-tubulin residues in benzimidazole activity: His6, Ala165, Phe167, Glu198, Phe200 and Arg241 (Thomas et al., 1985; Ohrbach et al., 1986; Jung \& Oakley, 1990; Fujimara et al., 1992; Jung et al., 1992; Li et al., 1996). Comparisons of the C. neoformans TUB1 and TUB2 sequences to $\beta$-tubulin sequences from benzimidazoleresistant and -sensitive organisms (such as those in Fig. 4) strongly suggest that TUB1 represents the basis for benzimidazole sensitivity. Specifically, Phe200, a residue that has been shown to be predictive of benzimidazole sensitivity in helminths, fungi and protozoa (Katiyar et al., 1994), is present in TUB1 but not in TUB2 $\beta$-tubulin. Glu198, also highly correlated with benzimidazole sensitivity, is only found in TUB1.

\section{Mutations conferring benzimidazole resistance}

The premise that $\beta$-tubulin, and specifically TUB1 $\beta$ tubulin, represents the basis for $C$. neoformans benzimidazole sensitivity was supported by the identi- fication of a His6 to Gln mutation in TUB1 from three independently isolated albendazole-resistant mutants. This residue has been previously implicated in benzimidazole activity in three fungi: A. nidulans (Jung et al., 1992), Trichoderma viride (Goldman et al., 1993) and Septoria nodorum (Cooley \& Caten, 1993). Furthermore, binding studies have shown that tubulin from an $A$. nidulans mutant with a His 6 to Leu mutation has a lower binding affinity for carbendazim compared to wild-type tubulin (Davidse \& Flach, 1977; Jung et al., 1992). This suggests that the resistance conferred by this mutation results from a direct effect on benzimidazole binding and not, for example, an indirect increase in microtubule stability.

All previously characterized fungal mutants were selected for resistance to benzimidazole derivatives substituted at the 2-position with either carbamate (benomyl and carbendazim) or thiazol (thiabendazole) but unsubstituted at the 5-position. Albendazole, on the other hand, is an anthelmintic carbamate derivative with a 5-propylthio group. The fact that mutations in His6 were selected with derivatives both substituted and unsubstituted at the 5-position suggests that His 6 does not interact with this side chain. Indeed, the relative effect of the C. neoformans mutation on sensitivity was greater for carbendazim ( $\geqslant 7$-fold increase in $50 \%$ inhibitory concentration) than for albendazole or fenbendazole (3.5-fold increase; data not shown). It would be of interest to further examine the role of $\beta$ tubulin residue 6 in benzimidazole binding by sitedirected mutagenesis (Li et al., 1996).

\section{ACKNOWLEDGEMENTS}

We thank Drs E. Spitzer and J. Edman for the C. neoformans gene libraries. This work was supported by Public Health Service grant AI-32433 from the National Institute of Allergy and Infectious Diseases.

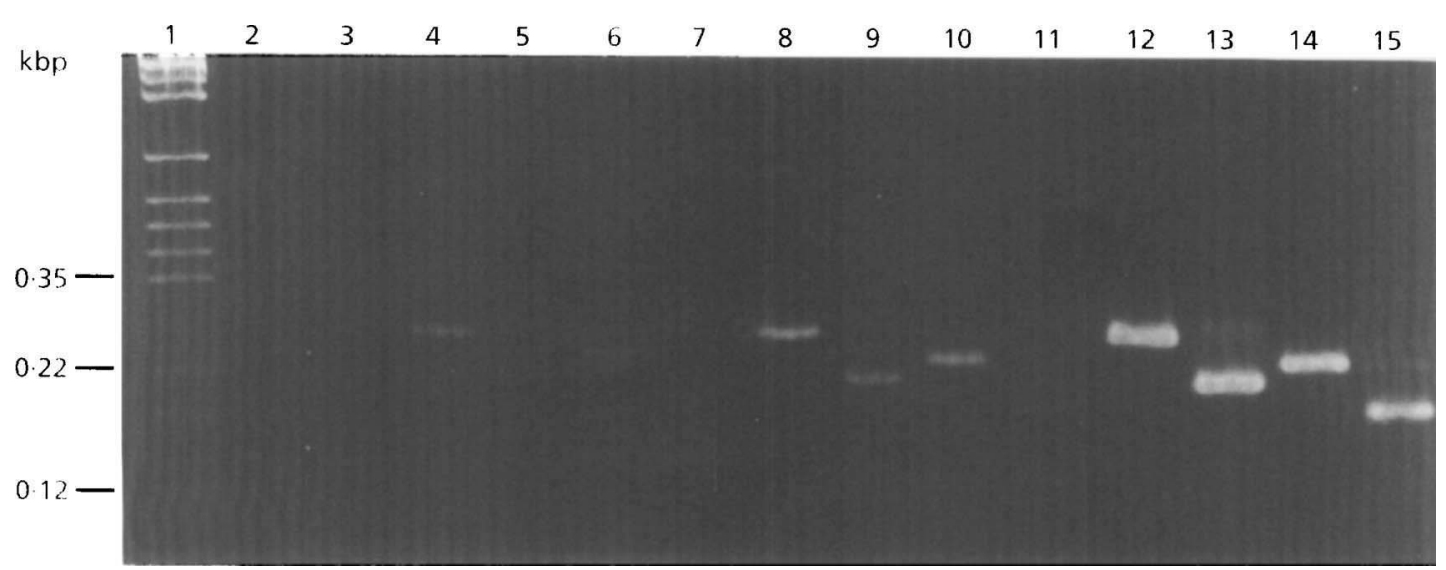

Fig. 5. RT-PCR analysis of the relative expression of TUB1 and TUB2. All lanes included the conserved downstream primer. TUB1-specific upstream primer was added to lanes 2, 4, 5, 8, 9, 12 and 13; TUB2-specific upstream primer was added to lanes $3,6,7,10,11,14$ and 15. Template CDNA was added to lanes 5, 7, 9, 11, 13 and 15; genomic DNA was added to lanes $4,6,8,10,12$, and 14 ; lanes 2 and 3 received $\mathrm{H}_{2} \mathrm{O}$ only. PCR was conducted for 20 (lanes 4-7), 22 (lanes 8-11) or 25 (lanes 2, 3 and 12-15) cycles. DNA size markers are in lane 1, with selected bands indicated. 


\section{REFERENCES}

Cooley, R. N. \& Caten, C. E. (1993). Molecular analysis of the Septoria nodorum $\beta$-tubulin gene and characterization of a benomyl-resistance mutation. Mol Gen Genet 237, 58-64.

Cruz, M. C., Barlett, M. S. \& Edlind, T. D. (1994). In vitro susceptibility of the opportunistic fungus Cryptococcus neoformans to anthelmintic benzimidazoles. Antimicrob Agents Chemother 38, 378-380.

Davidse, L. C. \& Flach, W. (1977). Differential binding of methyl benzimidazole-2-yl carbamate to fungal tubulin as a mechanism of resistance to this antimitotic agent in mutant strains of Aspergillus nidulans. J Cell Biol 72, 174-193.

Davis, L. G., Dibner, M. D. \& Battey, J. F. (1986). Basic Methods in Molecular Biology. New York: Elsevier.

Edman, J. C. \& Kwon-Chung, K. J. (1990). Isolation of the URA5 gene from Cryptococcus neoformans var. neoformans and its use as a selective marker for transformation. Mol Cell Biol 10, $4538-4544$.

Fujimara, M. K., Oeda, M., Inoue, H. \& Kato, T. (1992). A single amino-acid substitution in the $\beta$-tubulin gene of Neurospora crassa confers both carbendazim resistance and diethofencarb sensitivity. Curr Genet 21, 399-404.

Goldman, G. H., Temmerman, W., Jacobs, D., Contreras, R., Van Montagu, M. \& Herrrera-Estrella, A. (1993). A nucleotide substitution in one of the $\beta$-tubulin genes of Trichoderma viride confers resistance to the antimitotic drug methyl benzimidazole2-yl-carbamate. Mol Gen Genet 240, 73-80.

Hay, J. R. (1991). Clinical manifestations and management of cryptococcoses in the compromised patient. In Fungal Infection in the Compromised Patient. Edited by D. W. Warnock \& M. D. Richardson. New York: John Wiley.

Jung, M. K. \& Oakley, B. R. (1990). Identification of an amino acid substitution in the benA $\beta$-tubulin gene of Aspergillus nidulans that confers thiabendazole resistance and benomyl supersensitivity. Cell Motil Cytoskel 17, 87-94.

Jung, M. K., Wilder, I. B. \& Oakley, B. R. (1992). Amino acid alterations in the benA ( $\beta$-tubulin) gene of Aspergillus nidulans that confer benomyl resistance. Cell Motil Cytoskel 22, 170-174.

Katiyar, S. K. \& Edlind, T. D. (1994). $\beta$-Tubulin genes of Trichomonas vaginalis. Mol Biochem Parasitol 64, 33-42.

Katiyar, S. K., Gordon, V. R., McLaughlin, G. L. \& Edlind, T. D. (1994). Antiprotozoal activities of benzimidazoles and correlations with $\beta$-tubulin sequence. Antimicrob Agents Chemother 38, 2086-2090.

Kozak, M. (1986). Point mutations define a sequence flanking the AUG initiator codon that modulates translation by eukaryotic ribosomes. Cell 44, 283-292.
Lacey, E. (1988). The role of the cytoskeletal protein, tubulin, in the mode of action and mechanism of resistance to benzimidazoles. Int J Parasitol 18, 885-936.

Lewis, S. A., Gilmartin, M. E., Hall, J. L. \& Cowan, N. J. (1985). Three expressed sequences within the human $\beta$-tubulin multigene family each define a distinctive isotype. $J \mathrm{Mol}$ Biol 182, 11-20.

Li, J., Katiyar, S. K. \& Edlind, T. D. (1996). Site-directed mutagenesis of Saccharomyces cerevisiae $\beta$-tubulin: interaction between residue 167 and benzimidazole compounds. FEBS Lett 385, 7-10.

May, S. G., Tsang, M. L. S., Smith, H., Fidel, S. \& Morris, N. R. (1987). Aspergillus nidulans $\beta$-tubulin genes are unusually divergent. Gene 55, 231-243.

Moore, T. D. E. \& Edman, J. C. (1993). The $\alpha$-mating type locus of Cryptococcus neoformans contains a peptide pheromone gene. Mol Cell Biol 13, 1962-1970.

Ohrbach, M. J., Porro, E. B. \& Yanofsky, C. (1986). Cloning and characterization of the gene for $\beta$-tubulin from a benomyl resistant mutant of Neurospora crassa and its use as a dominant selectable marker. Mol Cell Biol 6, 2452-2461.

Panther, L. A. \& Sande, M. A. (1990). Cryptococcal meningitis in the acquired immunodeficiency syndrome. Semin Respir Infect $\mathbf{5}$, $138-145$.

Powderly, W. G. (1992). Therapy for cryptococcal meningitis in patients with AIDS. Clin Infect Dis 14, S54-S59.

Russo, P., Juuti, J. T. \& Raudaskoski, M. (1992). Cloning, sequence and expression of a $\beta$-tubulin-encoding gene in the homobasidiomycete Schizophyllum commune. Gene 119, 175-182.

Sirawaraporn, W., Cao, M., Santini, D. V. \& Edman, J. C. (1993). Cloning, expression, and characterization of Cryptococcus neoformans dihydrofolate reductase. J Biol Chem 268, 8888-8892.

Sugar, A. M., Stern J. J. \& Dupont, B. (1990). Overview : treatment of cryptococcal meningitis. Rev Infect Dis 12, S338-S348.

Thomas, J. H., Neff, N. F. \& Botstein, D. (1985). Isolation and characterization of mutations in the $\beta$-tubulin gene of Saccharomyces cerevisiae. Genetics 112, 715-734.

Tolkacheva, T., McNamara, P., Piekarz, E. \& Courchesne, W. (1994). Cloning of a Cryptococcus neoformans gene, GPA1, encoding a $G$-protein $\alpha$-subunit homolog. Infect Immun 62, 2849-2856.

Williamson, P. R. (1994). Biochemical and molecular characterization of the diphenol oxidase of Cryptococcus neoformans: identification as a laccase. J Bacteriol 176, 656-664.

Received 14 October 1996; revised 9 December 1996; accepted 7 February 1997. 